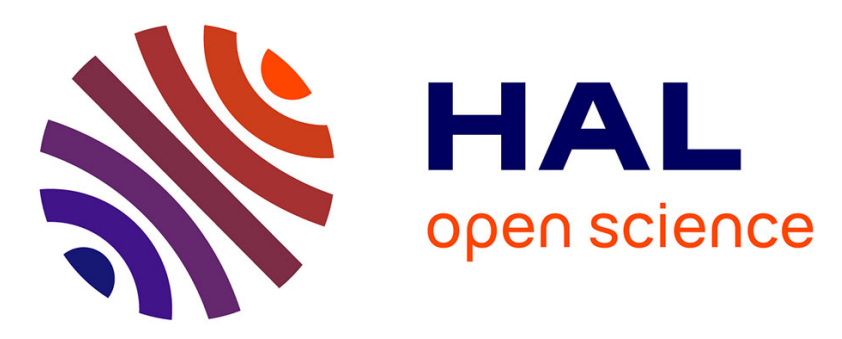

\title{
An empirical investigation of IT outsourcing vs. quasi-outsourcing in France and Germany
}

Jérôme Barthélemy, Dominique Geyer

\section{To cite this version:}

Jérôme Barthélemy, Dominique Geyer. An empirical investigation of IT outsourcing vs. quasioutsourcing in France and Germany. Information and Management, 2005, 42 (4), pp.533-542. 10.1016/j.im.2004.02.005 . hal-00764228

\section{HAL Id: hal-00764228 \\ https://hal.science/hal-00764228}

Submitted on 21 Feb 2014

HAL is a multi-disciplinary open access archive for the deposit and dissemination of scientific research documents, whether they are published or not. The documents may come from teaching and research institutions in France or abroad, or from public or private research centers.
L'archive ouverte pluridisciplinaire HAL, est destinée au dépôt et à la diffusion de documents scientifiques de niveau recherche, publiés ou non, émanant des établissements d'enseignement et de recherche français ou étrangers, des laboratoires publics ou privés. 


\title{
An Empirical Investigation of IT Outsourcing vs. Quasi-outsourcing in France and Germany
}

\author{
Jérôme Barthélemy \\ ESSEC - France \\ Dominique Geyer \\ AUDENCIA Nantes - France
}

\begin{abstract}
:
An increasingly large number of firms outsource their Information Technology (IT). Firms that contemplate IT outsourcing have two alternatives: (1) contract with a vendor (i.e., outsourcing) or (2) set up their own IT subsidiary (i.e. quasi-outsourcing). This study examines some of the determinants of the outsourcing vs. quasi-outsourcing decision. Using primary data collected in France and Germany, we show that the outsourcing vs. quasioutsourcing decision is strongly influenced by both internal (i.e., asset specificity, size and internal organization of IT) and external (i.e., institutional environment) determinants.
\end{abstract}

Key words:

MIS management, Outsourcing, France, Germany

----- Paper accepted for Information \& Management ----- 


\section{Introduction}

Information Technology (IT) outsourcing can be defined as "the transfer of property or decision rights in varying degrees over the IT infrastructure by a user organization to an external organization" [35]. IT outsourcing is not a new phenomenon. Time sharing for instance - which involves purchasing computer time - was very popular in the 1960s and 1970s. From the mid-1980s on however, a new type of IT outsourcing started blossoming. The main differences between this new type of IT outsourcing and more traditional IT outsourcing are the following [22]. First, outsourcing is no longer restricted to small and medium-sized companies that do not possess their own IT infrastructure. Larger companies also resort to IT outsourcing. Second, companies outsource an increasingly large range and depth of services. Third, personnel and equipment are frequently transferred to the vendor. Though this new type of IT outsourcing started developing in the mid-1980s, it really took off after the very much-heralded contract between Kodak and IBM in 1989. This landmark deal legitimized the practice of IT outsourcing among U.S. Fortune 500 firms [35].

Basically, firms that contemplate IT outsourcing have two alternatives: (1) contract with a vendor (i.e., "outsourcing") or (2) set up their own IT subsidiary (i.e. "quasi-outsourcing”). "Outsourcing" consist in transferring all or part of the IT activity to an outside vendor. The relationship with the vendor is then managed through a contract. As client-vendor relationships have "moved to the middle", there is a variety of contractual arrangements [12]. These contractual arrangements range from tight contracts to partnerships [19]. "Quasioutsourcing" consists in creating a subsidiary and transferring all or part of IT to this subsidiary. The basic idea of quasi-outsourcing is to transform an internal IT department into an associated entity that is empowered to behave like an external vendor. Quasi-outsourcing is also a way to free a former internal department from the bureaucratic restraints associated with being a support function of the value chain. However, quasi-outsourced IT departments 
can only expect to be successful if they can attract a sufficiently large number of external customers. Firms such as USX, Mellon Bank, Sears had only limited success with their IT subsidiaries [47]. On the other hand, Philips successfully spun off its development and operations IT activities in the 1990s [49].

The paper presents an empirical study that examines the determinants of IT outsourcing vs. quasi-outsourcing in France and Germany. More specifically, we show that the IT outsourcing vs. quasi-outsourcing decision is strongly influenced by both internal (i.e., asset specificity, size and internal organization of IT) and external (i.e., institutional environment) determinants.

\section{Research background}

\subsection{IT outsourcing}

IT outsourcing has received a lot of attention from the managerial literature [e.g., 13, 18, 30, 31]. The existing managerial literature on IT outsourcing generally revolves around a few key points. The first is whether IT should be outsourced or not. The second is how the relationship with the vendor should be managed. In most cases, the managerial literature draws lessons from highly visible companies that have been successful with outsourcing such as Continental Bank [24], British Petroleum [13] or Eastman Kodak [37].

The academic literature has also devoted a lot of attention to IT outsourcing. The topics studied in the academic literature closely mirror those dealt with by the managerial literature. Researchers have studied the impact of various determinants on IT outsourcing decisions. These determinants include the gap between actual and desired IT performance [46], transaction costs and production costs considerations [1], competing insights from the transaction cost, knowledge-based, agency and measurement literatures [42] as well as interactions between economic and institutional factors [2]. Regarding the management of 
outsourced IT activities, recent researches have focused on the impact of partnerships on outsourcing success $[22,33,34]$. The impact of transaction cost considerations on the terms and management of the contract has also been investigated [8]. Despite this large body of literature on IT outsourcing, the determinants of the IT outsourcing vs. quasi-outsourcing decision have never been examined by any published study of which we are aware.

\subsection{IT quasi-outsourcing}

In this paper, we introduce the concept of "IT quasi-outsourcing" to describe a situation where a company sets up its own IT subsidiary instead of contracting with a vendor. The concept to which quasi-outsourcing is the most closely related is that of spin-off. A spin-off can be defined as "a firm that is partially owned by the parent, but independently managed" [25]. There is a stream of research on U.S. spin-offs [e.g., 7, 44, 54]. Most of this research has focused on the analysis of the shareholder wealth effect of spin-offs. For instance, it has been recently shown that improving focus through spin-offs leads to higher firm value [e.g., 14, 15]. Despite their relatedness, the concepts of spin-off and quasi-outsourcing are quite different. The main difference is that the parent company needs to keep access to the service provided by the quasi-outsourced IT department.

Transaction Cost Economics (TCE) is a very useful theoretical lens to study organizational forms such as quasi-outsourcing $[50,52,53]$. TCE suggests that transactions can be organized either through markets or hierarchies. It identifies two costs to be considered in determining whether the appropriate governance structure for a transaction is a market or a hierarchy: production costs and transaction costs. Markets generally lead to smaller production costs due to the economies of scale enjoyed by suppliers [46]. However, markets lead to higher transaction costs arising from negotiating, monitoring and enforcing contracts (provided asset specificity, uncertainty and frequency are high). Accordingly, firms opt for 
outsourcing when production cost advantages override transaction diseconomies in market relationships.

While outsourcing is a change from a hierarchical transaction to a market relationship, quasi-outsourcing is a change from a hierarchical transaction to a quasi-market relationship. By choosing quasi-outsourcing instead of outsourcing, the parent corporation keeps a stronger control over the activity that has been outsourced $[4,5]$. Contracts are the most prominent safeguards to protect against the hazards of opportunism [21]. However, alternative means have been proposed. They include informal safeguards such as trust but also formal safeguards such as equity ownership $[16,52]$. Firms do not necessarily control opportunism through legal contracts but can also rely on self-enforcing safeguards. In transaction cost terms, quasi-outsourcing is a hybrid structure of governance that lies between market and hierarchy [51]. Quasi-outsourcing is a way to balance market and organizational transaction costs. While the productivity of internal IT departments is plagued with low powered incentives, arm's length relationships with IT vendors are plagued with the possibility of opportunistic expropriation [27]. Opportunistic expropriation occurs when vendors standardize IT to the extent that it becomes a commodity and the unique needs of the client are no longer met. Hence, the quality of service to the client can be significantly reduced [1].

\section{Research hypotheses}

The objective of the study is to explore the impact of internal and external determinants on the IT outsourcing vs. quasi-outsourcing decision. The research model and findings are summarized in Figure 1. 
Internal

Determinants
External

Determinants

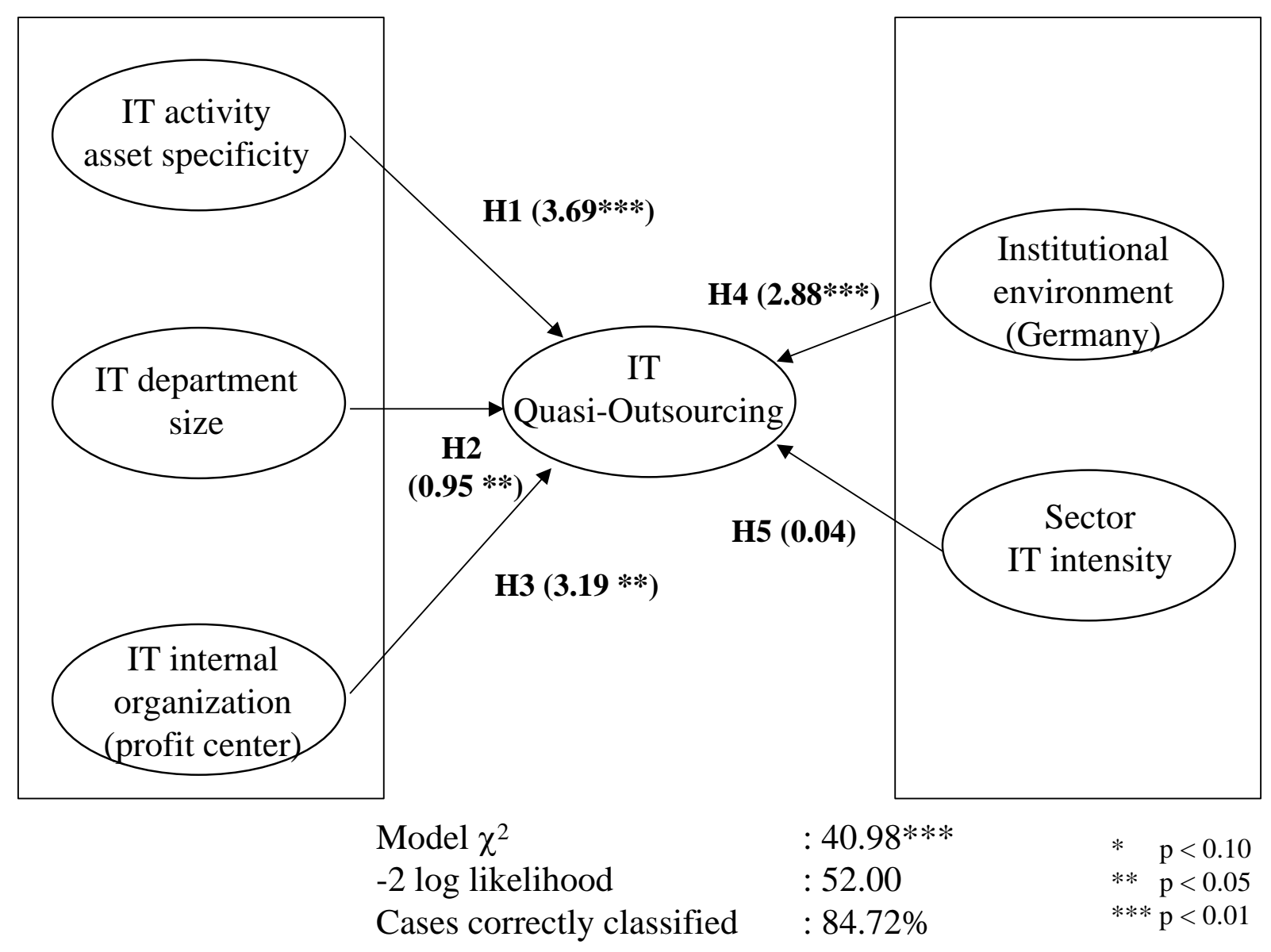

\subsection{Impact of IT activity asset-specificity}

The standard TCE reasoning is that as asset specificity increases, more complex governance structures are required to eliminate or attenuate costly bargaining over profits from specialized assets [52]. In the case of IT, it has been argued that the level of asset specificity is dependent on the type of activity ("Transaction cost economics posits that the relationships might vary based on the degree to which the production or service is assetspecific. While such assessment is dependent on the specific context being considered, it can be argued that certain IS functions are becoming increasingly standardized", [22, p. 96]). The IT activities that have become commodities include data centers (i.e., a highly structured 
activity that was one of the first to be outsourced), telecommunications networks and microcomputers (i.e., two activities that reflect the trend toward standardization and standard configurations in IT) [22]. On the other hand, IT activities such as applications development, system design and systems integration are closely tied to the specific needs of firms. Thus, they remain highly asset-specific.

Consistent with TCE, we contend that outsourcing highly asset-specific IT activities entails larger contractual hazards than outsourcing less asset-specific. Maintaining a relationship through equity ownership is a very powerful way to control a vendor. Hence, firms that outsource asset-specific IT activities should be more likely set up their own subsidiary than contract with an external vendor.

Hypothesis 1: For firms that outsource their IT, the likelihood of quasi-outsourcing is higher when IT activities are highly asset-specific.

\subsection{Impact of IT department size}

Cost reduction has been reported to be the most important motivation for IT outsourcing [29]. The theoretical basis of economies of scale is mass production and labor specialization. Mass production reduces costs by allocating fixed costs over more units of output while labor specialization reduces costs by allowing workers to focus on a limited range of tasks [52].

Vendors generally have a production cost advantage over their clients because they are able to pool demand and thereby achieve greater economies of scale. However, large vertically integrated firms also enjoy internal economies of scale due to their sheer size. In the case of IT, these internal economies of scale may be as large as the economies of scale enjoyed by specialized vendors $[9,28]$. This difference has an important impact on the outsourcing vs. quasi-outsourcing decision. For small firms, accessing the vendor's economies of scale is a necessity. Subsidiaries set up by small firms will not necessarily 
perform well enough to attract "external" customers and enjoy economies of scale. Though outsourcing entails higher contractual hazard than quasi-outsourcing, small firms are more likely to outsource to an outside vendor than set up their own subsidiary. For large firms, accessing the vendor's economies of scale is not a necessity. As quasi-outsourcing generally entails fewer contractual hazards than outsourcing, large firms are more likely to set up their own IT subsidiary than outsource to an outside vendor ceteris paribus.

Hypothesis 2: For firms that outsource their IT, the likelihood of quasi-outsourcing is higher when IT departments are large.

\subsection{Impact of IT internal organization}

A company is a collection of responsibility centers. Prior to the 1980s, IT was a cost center in most firms. There was no strenuous monitoring of IT and the high specificity of IT resources allowed budgets to grow without major constraint [6]. From the 1980s on, firms started turning IT cost centers into profit centers. Profit centers are essentially small firm subunits for which the hierarchical authority and behavioral monitoring that characterize internal governance have been reduced. Profit centers are expected to be more efficient than cost centers because their performance can be directly measured and rewarded $[3,10]$. As Zenger and Hesterly maked clear: "Disaggregation of a corporation into smaller firms or small, autonomous internal units affords access to high-powered incentives” [55, p. 212].

Profit centers have higher incentives than cost centers to reach a level of performance close to that of the best outside vendors. Hence, we propose a temporal cause-effect relationship saying that if IT was previously a profit center, then it is more likely to move to a quasi-outsourcing form of governance (compared to if IT was previously a cost center). In other words, firms are more likely to quasi-outsource IT profit centers than IT cost centers. 
Hypothesis 3: For firms that outsource their IT, the likelihood of quasi-outsourcing is higher when IT was a profit center than a cost center.

\subsection{Impact of institutional environment}

Despite persistent reaffirmation that the organization of firms in different countries increasingly becomes more alike, it has also been argued that distinct patterns persist [see 11 for the debate]. According to the "divergence hypothesis", management practices in a country partially reflect its institutional environment so that differences across countries exceed variations within countries [20]. Building upon the argument of North [39, 40], we argue that institutional differences have an impact on the choice between IT outsourcing and quasioutsourcing. North [40] defines institutions as the constraints, both formal and informal, that shape human interactions. Formal constraints refer to political rules, economic rules and contracts. Informal constraints refer to the norms and value system of a society. Institutions can raise or lower the transaction costs that must be borne to achieve a given level of cooperation. Hence, they directly or indirectly shape the conditions under which factors of production are created, deployed, and coordinated both within and among firms.

Three main factors may help explain why German firms are more likely to resort to IT quasi-outsourcing than their French counterparts: the presence of large industrial groups, the original system of co-management and the greater power of unions.

First, The German economy is characterized by the presence of large industrial groups (i.e., Konzerns). Interlocking ownership in Konzerns creates a high degree of interconnectedness between a large number of German firms [41]. This interconnectedness rests primarily on the tight bonds between German banks and manufacturers. On the other hand, the French banking structure is weaker and far more fragmented. French banks also work less closely with industrial firms. In Germany, the presence of Konzerns has a huge 
impact on the IT outsourcing vs. quasi-outsourcing decision. IT departments that have been quasi-outsourced can easily find customers among firms that belong to the same Konzern. For these customers, transacting with an IT vendor that belongs to the same Konzern is appealing because it entails lower costs than transacting with an IT vendor that does not. Within Konzerns, informal norms constrain the ability and willingness of individual members to engage in opportunistic behavior. These informal norms enable quasi-outsourced German IT departments to attract "external" customers even if they have no real cost or performance advantage compared to other IT vendors. On the other hand, quasi-outsourced IT departments in France cannot rely on these norms to attract "external" customers. Hence, German firms are more likely to resort to IT quasi-outsourcing than are French firms.

Second, the original system of co-management (Mitbestimmung) makes the German economy very different from that of other European countries. According to the German law of 1976 on co-management, a large part of the board of directors is composed of employee representatives. In most sectors, employee representatives represent one third of the members of the board of directors. The co-management system has substantial implications regarding the overall management of firms. One important implication is that the relationships between the employer and its employees are more cooperative in Germany than in other European countries such as France. For IT employees, being transferred to an outside vendor is often associated with trimmed benefits and lost seniority. On the other hand, quasi-outsourced IT employees are more likely to keep their seniority and most of their benefits. A direct implication is that German firms will be more likely to choose IT quasi-outsourcing, which is less detrimental to their employees.

Third, Germany is characterized by a small number of powerful unions. For instance, the D.G.B. (Deutsche Gewerkschaftsbund) has an almost hegemonic position. On the other hand, France has one of the lowest unionization rates among the OECD countries. Though there is a 
large number of unions in France, none of them is very powerful. The greater power of German trade unions make it easier for them to convince firms to choose quasi-outsourcing over outsourcing as this option is less detrimental to their employees.

Hypothesis 4: For firms that outsource their IT, the likelihood of IT quasi-outsourcing is higher in Germany than in France.

\subsection{Impact of sector IT intensity}

Quasi-outsourcing is a way to take advantage of innovative information systems to generate new revenues and profit. Due to the emergence of standard platforms, it becomes increasingly easy to resell applications developed in one firm to other firms in the same industry [47]. When they have their own core competencies, quasi-outsourced IT departments may even grow faster than their parent company, whose main business may be in declining stages of its life cycle [25]. We propose that firms with IT core competencies are more likely to come from IT intensive sectors such as banking/financial service/insurance and high tech than from other sectors [43]. Hence, firms from such IT intensive sectors should be more likely to set up IT subsidiaries than firms from less IT-intensive sectors.

Hypothesis 5: For firms that outsource their IT, the likelihood of quasi-outsourcing is higher in IT-intensive sectors.

\section{Research method}

This section presents the survey procedure and the sample used in this study. It then describes how the variables were operationalized. 


\subsection{Survey procedure}

A cross-sectional postal survey was developed for collecting primary data from a group of large French and German firms. A draft questionnaire was originally written in French and translated into German by a bilingual author. The draft questionnaire was simultaneously pretested with five French and seven German senior IT managers, which resulted in marginal modifications in the wording of some questions. The questionnaire was then sent to senior IT managers of the 500 largest French firms and the 500 largest German firms.

\subsection{Sample}

160 questionnaires were filled out by senior IT managers and returned (i.e. $12.2 \%$ of the French and $19.8 \%$ of the German samples). The overall response rate of $16 \%$ is low for two reasons. First, obtaining survey responses from IT executives is always problematic [42]. Second, financial constraints prevented us from sending reminders to non-respondents. However, a $16 \%$ response rate is consistent with recently published IT outsourcing studies [e.g., 42].

The breakdown of the sample by country and by industry is summarized in Table 1 . Overall, the structure of the French and German samples is very similar.

Table 1: Distribution of surveyed firms across sectors $(N=160)$

\begin{tabular}{lcccccc}
\hline Sector & \multicolumn{2}{c}{ French sample } & \multicolumn{2}{c}{ German sample } & \multicolumn{2}{c}{ Both samples } \\
\hline Energy \& extraction & 5 & $\mathbf{8 \%}$ & 13 & $\mathbf{1 3 \%}$ & 18 & $\mathbf{1 1 \%}$ \\
Raw materials and chemicals & 9 & $\mathbf{1 6 \%}$ & 14 & $\mathbf{1 4 \%}$ & 23 & $\mathbf{1 5 \%}$ \\
Manufacturing industry & 13 & $\mathbf{2 1 \%}$ & 17 & $\mathbf{1 7 \%}$ & 30 & $\mathbf{1 9 \%}$ \\
Trade/Food/Catering & 14 & $\mathbf{2 3 \%}$ & 21 & $\mathbf{2 2 \%}$ & 35 & $\mathbf{2 2 \%}$ \\
Banking/Finance/Insurance & 15 & $\mathbf{2 4 \%}$ & 24 & $\mathbf{2 5 \%}$ & 39 & $\mathbf{2 4 \%}$ \\
Others & 5 & $\mathbf{8 \%}$ & 10 & $\mathbf{1 0 \%}$ & 15 & $\mathbf{9 \%}$ \\
Total number of firms & 61 & $\mathbf{1 0 0 \%}$ & 99 & $\mathbf{1 0 0 \%}$ & 160 & $\mathbf{1 0 0 \%}$ \\
\hline
\end{tabular}


The goal of this study was to investigate the determinants of outsourcing vs. quasioutsourcing. However, the firms that responded to our questionnaire did not necessarily outsource all or part of their IT. Empirical studies on IT outsourcing generally distinguish between firms which outsource their IT and firms which do not. As the "IT outsourcing vs. no IT outsourcing" dichotomy does not account for the full range of attitudes towards IT outsourcing, we distinguished between four types of attitude towards IT outsourcing: (1) twenty-eight companies $(17.5 \%)$ of the total sample had not yet considered IT outsourcing; (2) nineteen companies $(11.9 \%)$ were examining the question of IT outsourcing but had not yet finalized their decision; (3) forty-one companies (25.6\%) had made a negative decision regarding IT outsourcing and (4) seventy-two companies (45.0\%) had actually outsourced their IT. Since we focus on firms that have made a positive IT outsourcing decision, our sample consists of seventy-two firms. Though the sample size is small, it is close to that of recently published IT outsourcing studies [e.g., 34].

\subsection{Variables}

We used the following variables to test our model. The dependent variable - quasioutsourcing - was a dummy variable coded " 1 " for quasi-outsourcing and " 0 " for outsourcing. All independent variables were measured at the time the IT outsourcing decision was made. IT activity asset-specificity was a dummy variable coded "1" for asset-specific IT activities and " 0 " for non asset-specific IT activities. Consistent with [22], we distinguished assetspecific IT activities (i.e., entire IT activity, applications development, systems design and systems integration) from non asset-specific IT activities (i.e., data centers, telecommunications networks and microcomputers). Though this type of measure is less common than perceptual ones, it may be more reliable than asking managers to remember how specific IT was at the time the outsourcing or quasi-outsourcing decision was made. IT 
department size was measured on a 5-point-Likert scale (i.e., "less than 20 people", "between 20 and 99 people", "between 100 and 499 people", "between 500 and 999 people" and "over 1000 people"). IT internal organization was a dummy variable coded " 1 " for profit center and “ 0 " for cost center. Institutional environment was a dummy variable coded " 1 " for Germany and "0" for France. IT-intensive sector was a dummy variable coded "1" for banking, financial services, insurance and aerospace sectors and " 0 " for other sectors.

As the dependent variables were measured with the same questionnaires as the independent variables, the risk was that common methods could skew the results (i.e., respondents may give self-justifying answers). In order to overcome the methodological limitations of selfreport measures, we use rough but objective measures for all variables.

\section{Analysis and results}

We tested our hypotheses using a binomial logistic regression model. For firms that outsourced all or part of their IT, the model estimated the influences of the independent variables on the likelihood of quasi-outsourcing. The logistic regression model took the following form:

Probability of choosing quasi-outsourcing $=1 /\left\{1+\exp ^{[-Y]}\right\}$

where $Y=\beta_{0}+\beta_{1} X_{1}+\beta_{2} X_{2}+\ldots+\beta_{\mathrm{p}} X_{\mathrm{p}}$

In this equation, $X_{1}, X_{2}, \ldots, X_{\mathrm{p}}$ were the explanatory variables, $\beta_{1}, \beta_{2}, \ldots, \beta_{\mathrm{p}}$ were the corresponding coefficients and $\beta_{0}$ was the intercept term. The parameters were estimated using maximum likelihood, employing the logistic regression procedure of the SPSS statistical package.

Table 2 reports the means, standard deviations, and correlations among the variables. The 
correlations showed strong bivariate association between IT quasi-outsourcing and all independent variables except IT-intensive sector. The maximum Variance Inflation Factor (VIF) was only 1.26 , which is well below the accepted rule of thumb value of 10 indicating multicollinearity problems [38].

Table 2: Means, standard deviations, and correlations among variables $(N=72)$

\begin{tabular}{lcccccccc}
\hline & Mean & S.D. & $\mathbf{1}$ & $\mathbf{2}$ & $\mathbf{3}$ & $\mathbf{4}$ & $\mathbf{5}$ & $\mathbf{6}$ \\
\hline 1. Quasi-outsourcing & 0.35 & 0.48 & 1.00 & $0.29^{* *}$ & $0.20^{*}$ & $0.40^{* * *}$ & $0.30^{* *}$ & 0.02 \\
2. Asset-specific IT activity & 0.69 & 0.46 & & 1.00 & -0.16 & 0.03 & $-0.30^{* *}$ & 0.03 \\
3. IT department size & 2.44 & 1.02 & & & 1.00 & 0.12 & -0.01 & 0.05 \\
4. IT internal organization & 0.61 & 0.49 & & & & 1.00 & 0.10 & -0.05 \\
5. Institutional environment & 0.60 & 0.49 & & & & & 1.00 & -0.10 \\
6. IT-intensive sector & 0.29 & 0.46 & & & & & & 1.00 \\
\hline$* \mathrm{p}<0.10, * * \mathrm{p}<0.05, * * * \mathrm{p}<0.01$ & & & & & & & &
\end{tabular}


Table 3 contains the results of the logistic regression.

Table 3: Results of the logistic regression

\begin{tabular}{lc}
\hline Variables & $3.69 * * *$ \\
\hline Asset-specific IT activity & $(1.04)$ \\
IT department size & $0.95 * *$ \\
& $(0.39)$ \\
IT internal organization & $3.19 * * *$ \\
& $(1.04)$ \\
Institutional environment & $2.88 * * *$ \\
& $(0.87)$ \\
IT-intensive sector & 0.04 \\
Intercept & $(0.76)$ \\
& $-10.02 * * *$ \\
\hline N & $(2.47)$ \\
Model $\chi^{2}$ & 72 \\
-2 log likelihood & $40.98 * * *$ \\
Cases correctly classified & with 5 d.f. \\
\hline p $<0.10, * * p<0.05, * * * p 0.01$ & 52.00 \\
Logitic & $84.72 \%$ \\
\hline
\end{tabular}

Logistic regression coefficients are reported. Standard errors are in parentheses.

The overall efficacy of the model was assessed using the likelihood ratio $\chi^{2}$, which is twice the difference in log likelihoods for the current model and the intercept-only model. The model was statistically significant $\left(\chi^{2}=40.98 ; p<0.001\right)$, which suggests that the variables discriminate well between IT outsourcing and quasi-outsourcing. The correct classification rate was $84.72 \%$, which suggests a good predictive ability.

All but one of our hypotheses were supported. Regarding the internal determinants of IT 
outsourcing vs. quasi-outsourcing decisions, we found support for all three hypotheses. Hypothesis 1 was supported. Firms that outsourced specific IT activities were more likely to set up a subsidiary $(\beta=3.69 ; p<0.01)$. The size of the IT department was also positively related to quasi-outsourcing $(\beta=0.95 ; p<0.05)$. As expected, IT departments that were profit centers before outsourcing took place were more likely to be quasi-outsourced than IT departments that were cost centers $(\beta=3.19 ; p<0.01)$. Thus, hypotheses 2 and 3 were supported.

Regarding the external determinants of IT outsourcing vs. quasi-outsourcing decisions, we found support for one of the two hypotheses. Hypothesis 4 stated that IT quasi-outsourcing was more frequent in Germany than in France because of differences in the institutional environment. As shown in Table 3, this hypothesis was supported $(\beta=2.88 ; p<0.01)$. On the other hand, firms from IT-intensive sectors did not more frequently resort to quasioutsourcing than firms from other sectors $(\beta=0.04 ; p>0.10)$. Thus, hypothesis 5 was not supported.

\section{Discussion}

The results of this study indicate that internal determinants have a huge impact on the IT outsourcing vs. quasi-outsourcing decision. The finding that quasi-outsourcing is more frequent than outsourcing for highly asset-specific IT activities is consistent with TCE. It confirms that firms use quasi-outsourcing to curb contractual hazard. The positive link between IT department size and quasi-outsourcing suggests that firms with large IT departments do not outsource to access the economies of scale enjoyed by vendors. As quasioutsourcing entails fewer contractual hazards than outsourcing, they are more likely to set up their own subsidiary than transfer their IT to an outside vendor. Hence, they can benefit from the high powered incentives of a market relationship while simultaneously economizing on 
transaction costs [26]. Another important finding is that IT departments organized as profit centers are more likely to be quasi-outsourced than IT departments organized as cost centers. That essentially stems from the fact that profit centers are more likely than cost centers to have the core competencies required to attract external customers. While empirical studies have tested the impact of various internal determinants on the IT outsourcing decision [e.g., 1, 8, 44], we are aware of no other research that focused on the IT outsourcing vs. quasioutsourcing alternative. Instead of dealing with the classic "market vs. hierarchy" issue, we have studied the alternative between the market and a hybrid organizational form.

A major finding of this article is that internal and external determinants play complementary roles in explaining IT outsourcing vs. quasi-outsourcing decisions. We found strong support for the hypothesis that IT quasi-outsourcing was more frequent in Germany than in France. Hence, the apparently universal character of IT outsourcing practices should not disguise the fact that national environments may influence them. The comparison between France and Germany is particularly interesting because of the important differences in management practices between the two countries [e.g., 45, 48]. While the impact of institutional differences on governance structures has been frequently studied in the case of Japan and the United-States [e.g., 4, 5, 17, 23], there is far less work comparing French and German institutional environments (see [36] for an exception). A casual reading of the French press (e.g. Le Monde Informatique, 01-Informatique) and German press (e.g. Computerwoche) suggests than German firms are more reluctant to resort to IT quasioutsourcing than their French counterparts. However, no large-scale empirical study has tackled this issue so far. Finally, we found no support for the hypothesis that firm in ITintensive industries were more likely to set up their own IT subsidiaries. One potential explanation is that IT quasi-outsourcing often involves reselling applications to other firms in the same sector. Firms able to resell sector-specific applications may be found in lots of 
different sectors (including low IT-intensive sectors such as retailing for instance). Hence, the lack of support for the relationship between IT-intensive sectors and quasi-outsourcing is not totally surprising.

\section{Conclusion}

The aim of this study was to provide a new angle on IT outsourcing research. First, we introduced IT quasi-outsourcing as an alternative organizational form between complete inhouse and complete outsourcing of IT. To our knowledge, no previous research had ever focused on IT quasi-outsourcing. Second, we assessed the impact of various determinants on the IT outsourcing vs. quasi-outsourcing decision. Our results confirmed that both internal (IT asset specificity, department size and internal organization) and external (institutional environment) factors had an impact on the actual decision. Thus, we believe that there is a need for more fine-grained research about specific forms of IT outsourcing and we hope that future research will consider quasi-outsourcing as a distinct governance form rather than combine it with traditional outsourcing.

Despite some meaningful implications, the paper also has several limitations. First, we focused on the outsourcing vs. quasi-outsourcing alternative. While our data cannot extend to these issues, it would be interesting to analyze both the decision to outsource, and if so, the decision to quasi-outsource instead of outsourcing. Second, our sample size was quite limited because only $45 \%$ of French and German firms actually outsourced all or part of their IT. This may be attributable to the fact that IT outsourcing is less frequent in France and Germany than in the United-States for instance. Third, our research is cross-sectional and it is impossible to figure out whether firms are increasing, decreasing, or keeping their current outsourcing level. Future research with a longitudinal design would be interesting. 


\section{References}

[1] S. Ang, L. Cummings (1997), Strategic response to institutional influences on information systems outsourcing, Organization Science, 8, 235-255

[2] S. Ang, D. Straub (1998), Production and transaction economies and IT outsourcing: a study of the US banking industry, MIS Quarterly, 535-548

[3] G. Akerlof (1970), The market for lemons: quality uncertainty and the market mechanism, Quarterly Journal of Economics, 84, 488-500

[4] M. Aoki (1990), Towards an economic model of the Japanese firm, Journal of Economic Literature, 28, 1-27

[5] M. Aoki (1988), Information, incentives and bargaining in the Japanese economy, Cambridge: Cambridge University Press

[6] L. Applegate, F McFarlan, W. McKenney (1999), Corporate Information Systems Management: Text and Cases, Boston: McGraw Hill

[7] D. Aron (1991), Using the capital market as a monitor: Corporate spinoffs in an agency framework, Rand Journal of Economics, Winter, 505-518

[8] B. Aubert, S. Rivard, M. Patry (1996), A transaction cost approach to outsourcing behavior : some empirical evidence, Information \& Management, 30, 51-64

[9] T. Barron (1992), Some new results in testing for economies of scale in computing, Decision Support Systems, 8, 405-429

[10] Y. Barzel (1982), Measurement cost and the organization of markets, Journal of Law \& Economics, 25, 27-48

[11] Berger, S., Dore, R. (1996), National Diversity and Global Capitalism, Ithaca, NY: Cornell University Press

[12] E. Clemons, S. Reddi, M. Row (1993), The Impact of IT on the Organization of Economic Activity: The "Move to the Middle" Hypothesis, Journal of Management Information Systems, 10, 9-35.

[13] J. Cross (1995), IT outsourcing: British Petroleum's competitive approach, Harvard Business Review, May-June, 94-102

[14] L. Daley, V. Mehrotra (1997), Corporate focus and value creation evidence from spinoffs, Journal of Financial Economics, 45, 2, 257-282

[15] H. Desai, P. Jain (1999), Firm performance and focus: Long-run stock market performance following spinoffs, Journal of Financial Economics, 54, 1, 75-102

[16] J. Dyer (1997), Effective interfirm collaboration : how firms minimize transaction costs and maximize transaction value, Strategic Management Journal, 18, 7, 535-556

[17] J. Dyer (1996), Does governance matter? Keiretsu alliances and asset specificity as sources of Japanese competitive advantage, Organization Science, 7, 649-666

[18] M. Earl (1996), The risks of outsourcing IT, Sloan Management Review, Spring, 26-32

[19] G. Fitzgerald, L. Willcocks, Contracts and Partnership in the Outsourcing of IT, Proceedings of the International Conference on Information Systems, Vancouver, B.C., 99-109

[20] Ghoshal, S., Bartlett, C. (1990), "The multinational corporation as an inter-organizational network", Academy of Management Review, 15, 4, 603-625

[21] Halvey, J., Melby, B. (1996), Information Technology outsourcing : process, strategies and contracts, New York: John Wiley \& Sons

[22] V. Grover, M. Cheon, J. Teng (1996), The effect of service quality and partnership on the outsourcing of information systems functions, Journal of Management Information Systems, 12, 4, 89-116

[23] C. Hill (1995), National institutional structures, transaction cost economizing and competitive advantage: the case of Japan, Organization Science, 6, 119-131 
[24] R. Huber (1993), How Continental Bank outsourced its crown jewels, Harvard Business Review, January-February, 121-129

[25] K. Ito (1995), Japanese spin-offs: unexplored survival strategies, Strategic Management Journal, 16, 431-446

[26] W. King, Y. Malhotra (2000), Developing a framework for analyzing IS sourcing, Information \& Management, 37, 323-334

[27] B. Klein, R. Crawford, A. Alchian (1978), Vertical integration, appropriable rents and the competitive contracting process, Journal of Law and Economics, XXI (2), 297-326

[28] M. Lacity, R. Hirschheim (1993), Information systems outsourcing, Chichester: John Wiley and Sons

[29] M. Lacity, L. Willcocks (1998), An empirical investigation of Information Technology sourcing practices: lessons from experience, MIS Quarterly, September, 363-408

[30] M. Lacity, L. Willcocks, D. Feeny (1995), IT outsourcing: maximize flexibility and control, Harvard Business Review, May-June, 84-93

[31] M. Lacity, L. Willcocks, D. Feeny (1996), The value of selective IT outsourcing, Sloan Management Review, Spring, 13-25

[32] P. Lawrence (1980), Managers and management in West Germany, London: Croom Helm

[33] J. Lee (2001), The impact of knowledge sharing, organizational capability and partnership quality on IS outsourcing success , Information \& Management, 38, 323-335

[34] J. Lee, Y. Kim (1999), Effect of partnership quality on IS outsourcing: Conceptual framework and empirical validation, Journal of Management Information Systems, 15, 4, 29-52

[35] L. Loh, N. Venkatraman (1992), Diffusion of Information Technology outsourcing: influence sources and the Kodak effect , Information Systems Research, 3, 4, 334-358

[36] M. Maurice, F. Sellier, J.-J. Silvestre (1982), Politique d'éducation et organisation industrielle en France et en Allemagne. Essai d'analyse sociétale, Paris: Presses Universitaires de France

[37] W. McFarlan, R. Nolan (1995), How to manage an IT outsourcing alliance, Sloan Management Review, Winter, 9-22

[38] J. Neter, W. Wasserman, \& M. Kutner (1985), Applied linear statistical models (2 ${ }^{\text {nd }}$ ed.), Homewood, IL: Irwin

[39] D. North (1981), Structure and change in economic history, New York: W. W. Norton \& Co

[40] D. North (1990), Institutions, Institutional change and economic performance, Cambridge: Cambridge University Press

[41] H. Pohl (1992), On the history of organizations and management in large German enterprises since the $19^{\text {th }}$ century, in B. Supple (ed.), The rise of big business, Aldershot: Edward Elgar

[42] L. Poppo, T. Zenger (1998), Testing alternative theories of the firm: transaction cost, knowledge-based and measurement explanations for make-or-buy in information services , Strategic Management Journal, 19, 853-877

[43] M. Porter, V. Millar (1985), How information gives you competitive advantage, Harvard Business Review, July-August, 149-160

[44] K. Schipper, A. Smith (1983), Effects of recontracting on shareholder wealth: The case of voluntary spinoffs, Journal of Financial Economics, December, 437-468

[45] A. Sorge (1993), Management in France; in D. Hickson (ed.), Management in Western Europe: Society, Culture and organization in twelve nations, Berlin: Walter de Gruyter, 65-87

[46] J. Teng, M. J. Cheon, V. Grover (1995), Decisions to outsource systems functions: 
testing a strategy-theoretic discrepancy model, Decision Science, vol. 26, 75-103

[47] N. Venkatraman (1997), Beyond outsourcing: managing IT resources as a value center, Sloan Management Review, Spring, 51-64

[48] M. Warner, A. Campbell (1993), German management, in D. Hickson (ed.), Management in Western Europe: Society, Culture and organization in twelve nations, Berlin: Walter de Gruyter, 89-108

[49] L. Willcocks, C. J. Choi (1995), Co-operative partnership and "total" IT outsourcing: from contractual obligation to strategic alliance, European Management Journal, 13, 6778

[50] O. Williamson (1996), The mechanisms of governance, Oxford : Oxford University Press

[51] O. Williamson (1991), Comparative economic organization: the analysis of discrete structural alternatives, Administrative Science Quarterly, 36, 269-296

[52] O. Williamson (1985), The economic institutions of capitalism, New York: Free Press

[53] O. Williamson (1975), Market and hierarchies: analysis and antitrust implications, New York: Free Press

[54] C. Woo, G. Willard, U. Daellenbach (1992), Spinoff performance: A case of overstated expectations?, Strategic Management Journal, 13(6), 433-447

[55] T. Zenger, W. Hesterly (1997), The disaggregation of corporations: selective intervention, high-powered incentives and molecular units , Organization Science, 8, 209222 